\title{
"I am part of the group, the others listen to me": theorising productive listening in mathematical group work
}

\author{
Marie Sjöblom $^{1}$ (D) $\cdot$ Tamsin Meaney $^{2}$ (D) \\ Accepted: 16 March 2021/ Published online: 13 April 2021 \\ (C) The Author(s) 2021
}

\begin{abstract}
Although group work is considered beneficial for problem solving, the listening that is needed for jointly solving mathematical problems is under-researched. In this article, the usefulness of two communication frameworks for understanding students' listening is examined, using data from an educational design research study in an upper secondary mathematics classroom in Sweden. From the analysis, it was apparent that these frameworks did not provide sufficient information about the complexity of listening in this context. Consequently, a new framework, "productive listening," is described which focuses on observable features connected to students' ability to show willingness to listen and to request listening from others. This framework included the purpose for listening, connected to problem-solving stages, and social aspects to do with respecting the speaker's contribution as being valuable and feeling that one's own contribution would be listened to. These two aspects are linked to socio-mathematical norms about expecting to listen to others' mathematical thinking and to ask clarifying questions about this thinking. By using this framework on the data from the earlier study, it was possible to better understand the complexity of listening in group work about mathematical problem solving.
\end{abstract}

Keywords Listening $\cdot$ Student interactions · Group work · Mathematical problem solving

\section{Listening in small group work for mathematical problem solving}

Although communication in small groups is considered to contribute to collective mathematics learning (Cobb et al., 2001; Walshaw \& Anthony, 2008), the role of listening in the work of these groups has been under-researched (Hintz \& Tyson, 2015). If listening in mathematical

Marie Sjöblom

marie.sjoblom@mau.se

1 Malmö University, SE-205 06 Malmö, Sweden

2 Western Norway University of Applied Sciences, Postboks 7030, 5020 Bergen, Norway 
communication is studied, it is often the role of the teacher, rather than students, that is in focus (see, for example, Hintz \& Tyson, 2015). For example, to maintain interactions focused on students' mathematical thinking and so on learning possibilities, Reeder and Abshire (2012) and Carpenter and Fennema (1992) highlighted the importance of teachers listening to students.

Communication practices, such as explaining their thinking, are needed if students are to learn how to participate in mathematical practices, like problem solving (Esmonde, 2009). In this article, we focus on problem solving, because "problem solving is not just about using mathematical skills appropriately, but also about interpreting, describing, and explaining situations mathematically" (Palmér, 2016, p. 255). Although listening is rarely explicitly mentioned in descriptions of communication practices to do with problem solving, clearly, if students are to add meaning to interactions, they need to have listened to other students. For example, Krummheuer (2015) used Sfard's (2008) ideas about learning as participation to describe four roles in interactions about problem solving: author, relayer, ghostee, and spokesperson. The author offers new content (semantic) and new grammatical structures (syntax), while the relayer offers neither, as usually they merely repeat what has been said by others. The ghostee uses a similar structure to what has been used earlier but puts into it their own ideas. The spokesperson uses their own words to express the ideas that someone else had described earlier. Krummheuer considered that ghostee and spokesperson were learners, as an author was likely to already know what they were expressing, while a relayer may not understand what they were repeating. To be able to make use of the structure or ideas of others' utterances, a group member must have listened.

Working in small groups on problem-solving tasks has been advocated for some time, with some of its value being linked to the social mechanisms that affect mathematical communication, "small problem-solving groups provide natural settings for interpersonal monitoring and regulating of members' goal-directed behaviors" (Artz \& Armour-Thomas, 1992, p. 148). Nevertheless, what affects students' willingness to engage in the kind of listening which supports joint problem solving in small group work is not fully understood. Thus, it is important to gain insights into the factors that affect students' listening, when solving mathematical problems in small groups.

To better understand the complexity of why and how students listen in mathematical group work, we describe the productive listening framework. This was developed as a result of an analysis of listening in problem-solving conversations (Sjöblom, 2015), which had used two frameworks that focused on communication in mathematics classroom interactions more generally (Alrø \& Skovsmose, 2004; Fuentes, 2009). In this analysis, it was clear that listening was more complex than these frameworks were able to show. Before describing the productive listening framework, we summarise previous research on listening in mathematics education, which also informed the development of the productive listening framework.

\section{Understandings about listening}

Research on listening has highlighted three aspects: definitions of listening, the purpose of listening, and the social aspects connected to who is being listened to. In the following sections, we discuss these and how they may contribute to problem-solving group work.

\subsection{Definitions of listening in mathematical group work}

Listening in mathematics education has been defined in a variety of ways. Of these, the most common is to distinguish between passive and active listening. Passive listening is when students do 
not interact with others about what they are hearing but do receive the speaker's meaning (Otten et al., 2011). By contrast, Kosko (2014) suggested that passive, silent students were disengaged from learning.

Active listening is generally considered to occur when students interact to gain meaning (Kosko, 2014), through "asking questions and giving non-verbal support while finding out what the other is getting at" (Alrø \& Skovsmose, 2004, p. 62). Students' learning is considered to improve when their questions are answered (Esmonde, 2009), highlighting the importance of active listening in this process. Results from analysing students' interactions in small groups showed that when students did not listen to each other, they were unable to formulate appropriate plans for mathematical problem solving (Artz \& Armour-Thomson, 1992).

Yet, it can be difficult to identify if students are listening actively in mathematical group work, making the distinction between active and passive listening difficult to use in research studies. Artz and Armour-Thomas (1992) claimed that when students were quiet during group work, but watching or listening to each other, it was not possible to assign a cognitive level to the activity since there was no verbalization between students. Similarly, Kosko (2014) concluded that "listening, in and of itself, is an unobservable action" (p. 216).

To overcome this difficulty, Kosko (2014) developed definitions of listening based on students' views of how they engaged in mathematical thinking while listening to others. He categorised students' engagement as doesn't happen — students explicitly stated that they did not listen; nothing happens - students claimed that their thinking was the same; learning happens - students engaged in some kind of cognition; math happens - students discovered/learned new mathematical information; and reflection happens - students compared/contrasted their thinking to that of other students. From his analysis of students' views, Kosko (2014) concluded that "students may engage in a continuum from passive to active listening" (p. 223).

Although Kosko's (2014) categories are interesting in that they focus on the relationship between listening and mathematical learning, they were not connected to classroom observations, but to students' self-evaluations that occurred afterwards.

Hintz and Tyson (2015), building on the work of Davis (1996, 1997), also categorised different kinds of listening. Their categories were evaluative — listening for something; interpretive hearing, responding, and trying to understand other's thoughts; and hermeneutic — a shared project between the persons in the interaction. These categorisations suggest that listening is done for a purpose.

\subsection{The purpose of listening in mathematics}

The information that is made available to be listened to and whether it is viewed as valuable by the listener is likely to affect whether and how listening occurs. In her study, Webel (2010) examined what made high school students feel responsible for asking/answering questions and giving/listening to explanations and justifications. She found that students had different opinions about what was important - the procedural explanation, the justification or the answer to the task, depending on what they considered was needed for engaging with mathematics.

Similarly, teachers' listening has been linked to what they wanted to achieve from listening. For example, Reeder and Abshire (2012) found that teachers needed to listen with intent to understand students' mathematical reasoning. Earlier, Carpenter and Fennema (1992) indicated that teachers learnt more about students' problem-solving skills when they explained less and listened more.

Nevertheless, teachers also have a role in supporting students to listen to each other. Mueller, Yankelewitz, and Maher (2014) suggested that teachers should promote student listening, by having 
them focus on why they were listening, for instance to understand other students' explanations, explain their solutions, and ask for help. If students are not facilitated in understanding the different purposes of listening, they would be unlikely to understand how these purposes might change during small group work.

\subsection{Social aspects connected to who is being listened to}

Listening is also affected by students' perceptions of the people they are expected to listen to. For instance, primary school students' willingness to interact in group discussions was affected by their perceptions of the social risk from giving incorrect solutions to mathematics tasks (Lack, 2010). Similarly, Bishop (2014) showed how students' willingness to talk and interact was related to who they were and could become in regard to mathematics.

Students also need to view others as having something worthwhile to contribute to the interactions. In Boaler's (2011) description of a study in which she and her graduate students taught sixth and seventh grade students, they reported that the teachers spent 6 weeks supporting students to listen to each other and respect each other. This is needed as it has been noted that students only valued some contributions (Webel, 2010). Webel (2010) found that some students considered that only the teacher was worth listening to, while others also valued their peers' help in their mathematics learning. In group work, Barnes (2005) identified that some students were ignored and treated as if they did not have the same rights as other students to participate in mathematical discussions. She stressed the importance of investigating how social factors affected communication in group work. In regard to Krummheuer's (2015) ghostee and spokesperson roles, it seems unlikely that students would use the content or grammatical structures of other students' utterances, if they did not consider those students had something valuable to contribute.

Views about who is worth listening to are connected to what Cobb et al. (2001) described as social as well as socio-mathematical norms. Social norms affect general classrooms activities. For example, at the beginning of her study, Hunter (2009) suggested that students saw learning as a process in which they listened to the teacher without interrupting. This is a social norm because it is about the relationship between people, in this case, the teacher and the students, which affects their behaviour, but is not specific to mathematics. On the other hand, socio-mathematical norms are related to mathematics. For instance, the kinds of questions students consider to be appropriate to ask or answer while working together in small groups on mathematical problem solving would be related to socio-mathematical norms, connected to classroom expectations about the mathematical purposes of listening.

To better understand the role of listening in small group work, there is a need to consider how the definitions of listening, the purposes of listening, and the social aspects contribute to the complexity of listening.

\section{The educational design research study}

To understand the role of listening in problem-solving group work, data from an educational design research (EDR) study was used (Sjöblom, 2015). In the EDR study, there were 24 students, about 16 years old, in their first year of an upper secondary programme in Sweden. The normal classroom teacher was responsible for leading the activities in the classroom. 
The classroom was multilingual, with at least nine different languages spoken by the students. As a majority of the students said that all of their schooling was in Swedish and that they rarely spoke their home languages in the classroom, the EDR study focused on the students' interactions in Swedish.

The purpose of the EDR study was to improve student-to-student interactions, so that all students were given opportunities to develop their reasoning and communication skills in mathematics while working with mathematical problem solving in small groups (Sjöblom, 2015). In educational design research studies (McKenney \& Reeves, 2012), a cyclic process is used to achieve both theoretical and practical results (Cobb \& Gravemeijer, 2008). Each cycle contains three phases: analysis, design, and evaluation (McKenney \& Reeves, 2012). Three cycles were conducted over one semester. Each cycle trialled a set of problem-solving tasks and support means, such as giving students specific communicative roles and providing lists of questions and of problem-solving strategies, based on the work on Polya (2014).

The communicative roles were chosen so that students had particular roles in which they took responsibility for active participation within the group (in line with the study of Cohen et al., 1999). During the first cycle, the communicative roles were a chairperson who determined who talked when, a summariser who wrote down the conclusions of the group, a thinker who was to think out loud, and a presenter who presented the conclusions in a whole-class discussion ${ }^{1}$. These roles and descriptions were adjusted in the second and third cycles. The communicative roles implicitly required the students to listen. The chairperson and summariser roles, similar to Krummheuer's (2015) ghostee and spokesperson roles, required these students to listen to others, while the thinker and presenter required others to listen to them.

The support means included a list of problem-solving strategies (building on Polya, 2014) and a question list, where the groups were expected to write down questions they used. These support means implicitly required students to listen to other group members and were also adjusted as a result of the first and second cycles. The tasks and support means were designed by the first author in collaboration with the students' teacher.

In the classroom, 3-4 students worked in gender-mixed groups. In each cycle, groups who gave informed consent were audio-recorded, while they worked on the mathematical problems (three groups in cycles 1 and 2 and two groups in cycle 3 ). ${ }^{2}$ Also, after each cycle, students were interviewed in their groups about their views on problem solving and their interactions. The students often made comments about the listening in their groups.

\section{The three stages in the development of the productive listening framework}

The three stages in the development of our productive listening framework are illustrated in Fig. 1. The first stage was a collaboration between the first author and the teacher as a

\footnotetext{
${ }^{1}$ In some of the groups, there were only three students. Then the role of the Thinker was taken away.

${ }^{2}$ Only the students who agreed to be recorded were part of the recordings, while all students in the classroom worked with the problem-solving tasks. In the third cycle, some students were absent on the day of recording, and therefore, only two groups were recorded.
} 


\begin{tabular}{|l|l|l|l|}
\hline $\begin{array}{l}\text { Stage 1. Analysis } \\
\text { using the IC- } \\
\text { model and } \\
\text { Fuentes } \\
\text { framework }\end{array}$ & $\begin{array}{l}\text { Stage 2. } \\
\text { Development of } \\
\text { a framework on } \\
\text { productive } \\
\text { listening }\end{array}$
\end{tabular}$\longrightarrow$\begin{tabular}{l}
$\begin{array}{l}\text { Stage 3. Analysis using } \\
\text { the productive listening } \\
\text { framework to understand } \\
\text { more about the } \\
\text { complexity of listening }\end{array}$ \\
\cline { 2 - 3 }
\end{tabular}

Fig. 1 Research process in three stages

part of the EDR process. In this stage, the inquiry co-operation model, IC-model (Alrø \& Skovsmose, 2004), and Fuentes' (2009) framework were used by the first author to understand what contributed to the interactions in the group work. The results were discussed with the teacher, and from these discussions, changes were made to the tasks and support means for the next cycle. It soon became apparent that students' listening needed to change in order to improve student-to-student interactions about problem solving.

The second stage occurred after the completion of the EDR cycles by both authors, and is part of the theoretical outcome of the EDR study. Although the frameworks used in the first stage of the research process identified some aspects of listening, they did not identify how the aspects operated together and thus only provided limited insights into the complexity of listening in small group work on problem solving. The outcome of this stage was a description of the productive listening framework.

In the third stage, some of the data were re-analysed using the productive listening framework, to illustrate the complexity of how and why students listen and the role of listening in problem-solving group work.

\subsection{Stage 1: analysis using the IC-model and Fuentes' framework}

In the EDR study, two frameworks - Alrø and Skovsmose's (2004) IC-model and Fuentes' (2009) framework - were used to analyse the small group work interactions. The frameworks were originally chosen because they highlighted different aspects of mathematical communication needed for problem solving (Sjöblom, 2014). Combining them allowed an initial identification of what affected the students' interactions.

\subsubsection{The IC-model}

Alrø and Skovsmose (2004) described the IC-model as having a set of eight dialogic acts related to mathematical communication but focused on how students interacted with a teacher. The eight dialogic acts in the IC-model are getting-in-contact ${ }^{3}$ (prepare for interaction), locating (understand the problem), identifying (find the mathematics in the

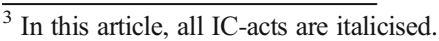


problem), advocating (examine ideas), thinking aloud (make perspectives and thoughts visible), reformulating (clarify and rephrase), challenging (question), and evaluating (look back at the problem).

All the acts could incorporate active listening (Otten et al., 2011) and highlight the importance of the purpose of listening (Webel, 2010). For example, getting-in-contact explicitly identifies listening, as it is about students listening to each other "in a relation of mutual respect, responsibility and confidence" (Alrø \& Skovsmose, 2004, p. 101). Also, the model suggests that when students engage with mathematics tasks while locating, identifying, or advocating, they need to pay attention and listen to each other's ideas to reinforce cooperative learning. Similarly, thinking aloud has the potential for identifying when students listen to what others think. In order to reformulate, challenge, or evaluate, students also need to listen, so their responses take into consideration other students' perspectives. An analysis using the dialogic acts, therefore, provides an opportunity to identify how and in what ways listening was used in small group interactions, but only at the general level and not specifically connected to problem solving.

\subsubsection{Fuentes' framework}

The second framework, by Fuentes (2009), classifies student conversations as eight question/comment-response pairs (QCR-pairs). This framework provides a more finegrained analysis of the interactions than the IC-model and adds extra information about how listening contributes to the mathematical group work (Table 1).

In Fuentes' framework, it can be assumed that students engage in active listening (Kosko, 2014) because they are expected to act on what they hear either by asking questions or responding to questions. The purpose of listening is connected to what the types of questions and responses are focused on. Nevertheless, in Fuentes' (2009) framework, most QCR-pairs presume that the interactions occur between a pair of students. For instance, it might be that $\mathrm{A}$ and $\mathrm{B}$ are talking, but that $\mathrm{C}$ is only listening, either by for instance eavesdropping or overhearing (Goffman, 1981), making it difficult to identify if they are engaged or not in the learning.

Table 1 Fuentes' framework for analysing student communication

\begin{tabular}{lll}
\hline QCR-pair & Question/Comment & Response \\
\hline 1 & A asks B to show work & B shows own work \\
2 & A asks B to explain work & B explains own work \\
3 & A criticises B's work & B justifies own work \\
4 & A rejects B's justification & B reconstructs own work \\
5 & A asks B to evaluate work & B evaluates A's work \\
6 & A suggests a strategy to the group & The group tries the strategy \\
7 & A asks B a content question & B answers A's question \\
8 & A asks B a clarification question & B answers A's question \\
\hline
\end{tabular}




\subsubsection{Analysis using the two frameworks}

By identifying the IC-acts and QCR-pairs in the group work interactions across the three cycles, it was possible to draw conclusions about which aspects of listening were captured and which were missed. This gave information about the problematique connected to students' listening in small group work. This can be seen in the analysis of the following two transcripts.

In the first cycle of the EDR study, the students' attempts to talk together in the groups rarely contributed to joint problem solving. The analysis showed an absence of IC-acts and QCR-pairs. For example, in Transcript 1 (cycle 1, the Dice game, Azad, Carlos, Mohammed, Mustafa, 25:56 ${ }^{4}$ ), the members of one group tried to drown out each other's contributions, when presenting their own strategies. The problem they were supposed to solve was about the most common total when adding the amounts from rolling two dice together.

Transcript 1.

1 Azad: I do not know if I am right, or if I just talk... Azad: Jag vet inte om jag har rätt eller jag snackar...

2 Carlos: But I think it is 10. Look here. You can have 5 and 5.

3 Azad: 10 and 8.10 and 8.

4 Carlos: You can have 4 and 6. You can...

5 Azad: Look here. Count how many times you can get 8 . Because, I think it is the same.

6 Carlos: (laughs)

7 Azad: Hey, Carlos. I think you can... Carlos I think 10 and 8.

8 Carlos: (laughs)... 12 minus 2...

9 Azad: (punches Carlos)

Carlos: Men jag tror att det är 10, för kolla här.

Man kan ha 5 och 5 .

Azad: 10 och 8.10 och 8 .

Carlos: Man kan ha 4 och 6. Man kan...

Azad: Men titta här. Räkna ut också hur många gånger du kan få 8 . För jag tror att du kan få lika många.

Carlos: (skrattar)

Azad: Hej, Carlos. Jag tror du kan få... Carlos, jag tror du kan få 10 och 8 .

Carlos: (skrattar)... 12 minus 2...

Azad: (slår till Carlos)

In Transcript 1, only two students in the group spoke, with each one wanting to pursue his own solution strategy, rather than building on the suggestions from the other, as part of joint advocating. Although they seemed to be using the IC-act thinking aloud (Alrø \& Skovsmose, 2004) (for instance, lines 2-4), there was no expectation that others would listen to them. No one asked follow-up questions, and so there were no QCR-pairs. Although both students used the phrase "look here" (lines 2 and 5), to gain the others' attention, suggesting the IC-act getting-in-contact, they did not achieve this outcome, which affected the group's possibilities of identifying the mathematics in the task. If the group had tried a solution strategy and worked with advocating ideas together, it would have been classified as Fuentes' (2009) QCR-pair 6, but there was no response by other members of the group, making it difficult to understand what was happening. By not responding, it seemed that no one considered other group members as having relevant contributions for solving the mathematical problem.

In Transcript 2, four students discussed a mathematical problem, in which two people, Johannes and Marie, had borrowed different amounts of money but still had to pay back the

\footnotetext{
$\overline{4}$ The position of a transcript is noted by the number of minutes and seconds in the interaction it comes from.
} 
same amount each month, as the interest rates were different. The students were expected to calculate the interest rates (cycle 2: Amal, Azad, Mohammed, Nour, 18:14):

Transcript 2.

1 Azad: Have you understood the task?

2 Mohammed: Have you understood the task? Johannes has borrowed two... Johannes has borrowed twice as much as Marie.

3 Azad: Wait, let us start like this, which questions do we need to ask to solve the task?

4 Nour: At the same time. Not the same amount. I kind of did an example. 50 crowns and 100 crowns. But, then, if she pays $5 \ldots$ what was it?

5 Nour + Amal: She pays three percent.

6 Amal: But still the same amount, although he pays 6 percent.

7 Nour: Yes, and that is..

8 Amal: It is she who has borrowed more, twice.

9 Azad: If they pay the same amount, then she... has to pay more than him for it to be... twice as much, but I am not sure..

10 Mohammed: Yes, yes, that is true.

11 Azad: But we have to ask questions before we start.

12 Mohammed: Do you know why it is twice as much?
Azad: Har ni fattat den?

Mohammed: Har ni fattat den? Johannes har lånat två... alltså Johannes har lånat dubbelt så mycket som Marie.

Azad: Vänta vi börjar såhär: vilka frågor ska vi ställa oss själva för att lösa uppgiften?

Nour: Samtidigt, inte lika mycket. Om typ jag tog ett exempel. 50 kronor och 100 kronor. Men sedan om hon betalar $5 \ldots$ vad var det?

Nour + Amal: Hon betalar tre procent

Amal: Men ändå lika mycket fast han betalar sex procent

Nour: Ja, och det blir..

Amal: Så det är hon som har lånat mer två gånger.

Azad: Om de betalar lika mycket måste hon den andra betala mer än honom för att det ska bli... dubbelt så mycket, men jag är inte säker...

Mohammed: Jojo, det är så ju.

Azad: Fast, vi måste ställa frågor innan vi kan börja.

Mohammed: Vet du varför det är dubbelt så mycket?

We consider this to be an example of joint advocating, where Azad and Mohammed tried to get-in-contact first, by asking if everyone had understood the task (lines 1-2). Azad (lines 1, 3, and 11) took seriously his communicative role of asking questions of others. His first attempt (line 3) showed a willingness to initiate interactions. However, it seemed that Nour and Amal had already started thinking about the task and, hence, ignored him. Nour then began thinking aloud (line 4) by asking herself a question about an example with 50 crowns and 100 crowns (QCR-pair 6). Amal helped her locating (QCR-pair 7) the mathematics in the task and the two girls cooperated to find a solution (lines 5-8). Azad reformulated the girls' conclusion (line 9), which was only possible if he had originally listened to them, similar to Krummheuer's (2015) spokesperson's role. However, he did it in an advocating way, by inviting the others to listen to him (Alrø \& Skovsmose 2004), as his thoughts were incomplete. By saying "I am not sure," he showed willingness to listen to others who might have had different ideas and wanted to challenge his conclusion. By doing this, he opened up the discussions so that others could think differently and evaluate his thoughts (QCR-pair 5). In the last lines, when Azad again emphasised the need to ask questions, Mohammed asked a question (lines 11-12) suggesting that he had listened to Azad.

In Transcript 2, students initiated and maintained interactions and from this tried to build a solution strategy by listening to each other's suggestions and asking questions. This is what Hintz and Tyson (2015) would categorise as hermeneutic listening because it focused on a joint project. Both the initiation and maintenance of the interaction were important for this joint project, given that the students requested listening as well as showed willingness to listen to each other. For example, by reformulating Amal's conclusion (line 9), Azad indicated that not only had he heard what she said, but she should now listen to his response to her conclusion in order to find out about his thinking. This could be the equivalent of Hintz and Tyson's (2015) interpretive listening. 
Reformulating part of an earlier contribution occurred when each person accepted that they had a responsibility to initiate and maintain the interaction in respectful ways.

Although the IC-model (Alrø \& Skovsmose, 2004) and Fuentes' (2009) framework uncovered some aspect to do with listening, there were other issues, not directly related to communication patterns and dialogic acts, which were not highlighted. For example, when students listened to each other, without asking questions or reacting in the ways suggested in the QCR-pairs, it was not possible to analyse these interactions. While some students worked with locating and identifying, it was hard to conclude if the quiet students listened or chose not to participate. Also, it was only when the mathematics was in focus that the IC-model provided insights into the purpose for listening. To be able to use the different IC-acts, students needed to listen, but as Transcripts 1 and 2 show, students sometimes had other reasons than mathematical ones for listening or not listening to each other, such as deciding who could talk or wanting to change the direction of the discussion. In the same way, Fuentes' (2009) framework could only be used to conduct an analysis when questions were answered. Azad in cycle 2 wanted the others to ask questions, but the reason for asking those questions sometimes seemed lost, making it not always easy to see the connection between the question and the response. It was not clear how Fuentes' framework could be used to analyse when and why student were willing to listen to each other or wanted other students to listen to them.

Other frameworks which focussed specifically on listening, such as Hintz and Tyson (2015), did not provide a better understanding, because they were about specific kinds of listening, and when no listening seemed to occur, it was not possible to describe these situations, such as what was seen in cycle 1, even as passive listening. Moreover, none of the frameworks provided insights into what affected the purpose that students had for listening, or how social or socio-mathematical norms affected why students chose to talk or to be quiet and in what situations they wanted to listen to each other.

\subsection{Stage 2: development of a framework on productive listening}

As a result of identifying that the frameworks did not provide sufficient insights into the students' listening in small group work, we designed the productive listening framework (see Fig. 2) based on the three aspects identified in the earlier literature review: definition of listening, purpose of listening, and how social aspects affect listening in small group problemsolving work. The relationship between these three aspects is organised to reflect the specificness of listening in small group work on problem solving.

Given the difficulties, previously noted, with the distinction between active and passive listening, listening for small group work was defined as "productive listening," based on observable actions: students requesting listening from other students and students showing willingness to listen, for instance by waiting for answers to questions, before continuing. The definition of productive listening reflected what was seen in the EDR study and drew on the work of Hintz and Tyson (2015) who concluded that students needed to know what to listen for, be interested in each other's thoughts, and cooperate in a common project in their mathematical discussions.

In Fig. 2, the purpose for listening is separated into three aspects which can be loosely related to Polya's (2014) problem-solving process. The four stages of Polya for problem solving were to understand the problem, devise the plan, carry out the plan, and look back. The purposes for listening are connected to understanding the problem, identifying key information for determining a solution strategy (connected to devise the plan), and identifying what works and what needs improving with the solution strategy (connected 


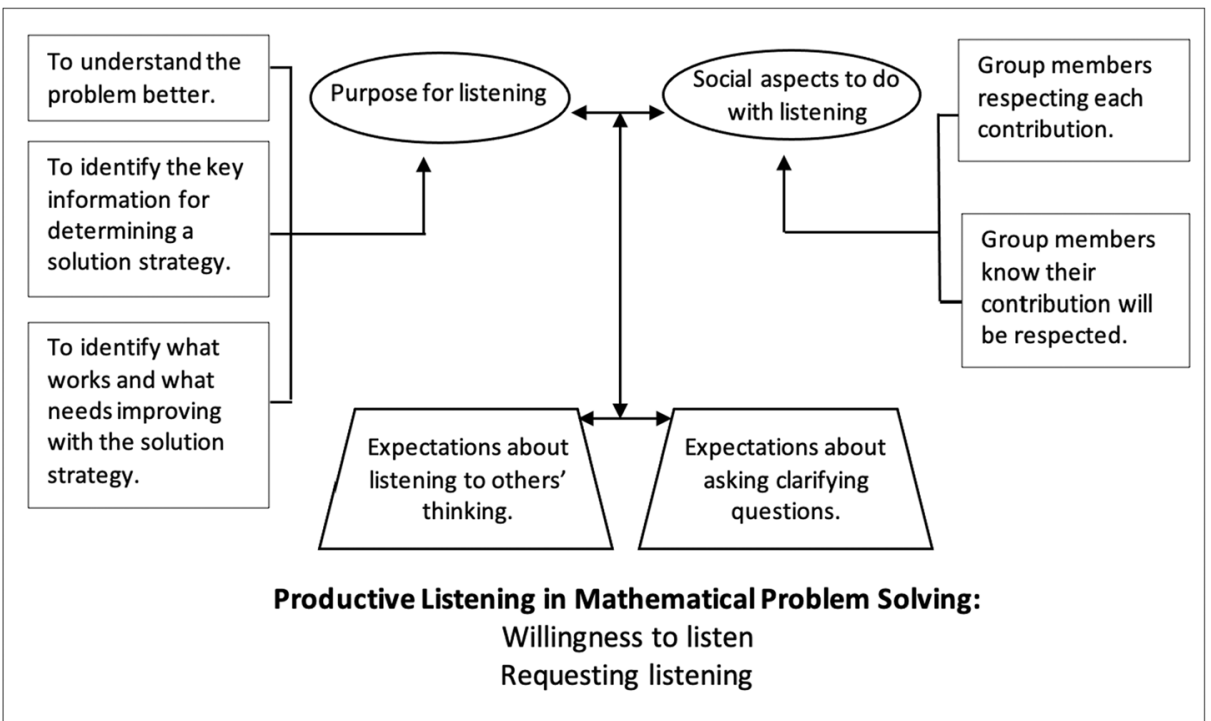

Fig. 2 The productive listening framework for mathematical group work

to carrying out the plan). A fourth point about checking the result against the problem could have been added to reflect Polya's fourth stage, but there were no examples on this in our data. In future work, considerations about how to engage students in their small groups with this fourth stage of problem solving would also require a change in the listening framework.

The social aspects of listening are related to the group member's contributions being respected by the listener and to group members knowing that their contributions will be respected (Barnes, 2005; Bishop, 2014). In Transcript 1, they were not evident, while in Transcript 2, they were more often visible in the interaction.

For listening to contribute to group problem solving, there was a need to establish sociomathematical norms about expecting to listen to others' mathematical thinking and about asking clarifying questions. These socio-mathematical norms merged the purposes for listening with the social aspects of listening. Our contention is that it is important to understand how listening contributes to problem solving in small groups to identify whether such sociomathematical norms are in operation. The socio-mathematical norms are made visible through students' actions of showing willingness to listen or by requesting listening in mathematical problem solving.

\subsection{Stage 3: analysis using the productive listening framework to understand more about the complexity of listening}

In the third stage of the development of the productive listening framework, we analyse data from the three cycles of the EDR project with this framework. The analysis illustrates how the productive listening framework provides insights into the complexity of listening in problemsolving group work by identifying how the different aspects interact. 


\subsubsection{Cycle 1: lack of understanding for the purpose of listening}

In Transcript 1, there seemed to be a competition between the two students about being heard, which resulted in them having difficulty respecting each other's contribution. This led to frustration, with Azad pushing Carlos at the end of the extract. This lack of respect made it difficult for Azad's requests for listening ("Look here" and "Hey Carlos") to be responded to appropriately. Carlos seemed uninterested in listening to understand the problem, identify key information, or to determine how the solution strategy could be improved. There seemed to be no established classroom expectations about listening to others' mathematical thinking or asking clarifying questions about that thinking.

In the interviews after the first cycle, when asked how they worked with questions, the students seemed unwilling to admit there were any problems (Interview cycle 1: Azad, Mohammed, 3:42):

Transcript 3.

1 Azad: There was no need... everyone was active anyway. Azad: Behövdes inte... alla var ändå aktiva.

2 Mohammed: Everyone knew the questions. Everyone. Mohammed: Alla kunde frågorna. Vi alla.

3 Azad: All are active people.

Azad: Alla är aktiva som personer.

4 Mohammed: We did not need to ask each other questions. Mohammed: Vi behövde inte ställa frågor till varandra.

The responses given in Transcript 3 indicate that students were aware that they were expected to ask questions to gain information but seemed uncertain why this was necessary. Asking questions did not seem to be connected to showing that they were active in the problem solving. There did not seem to be a socio-mathematical norm in place about the need to ask clarifying questions to gain information connected to the purposes of listening. This affected both their willingness to listen and the importance of requesting listening.

As in Fuentes' (2009) intervention study, when the students did not value others' mathematical contributions to solving mathematical problems, there were almost no possibilities for jointly constructing mathematical solutions, through active listening (Otten et al., 2011). Some students noted that they did value the information that others could contribute, but they did not know how to facilitate gaining it. For example, Amal and Nour talked about how quiet the two boys in their group were and that they wanted to hear what the boys knew and thought (Interview cycle 1: Amal, Nour, 9:56). These statements suggested that the girls were willing to listen but did not see that they had a responsibility to promote this nor that they had the necessary skills to do so. Unlike Barnes' (2005) results, the group members were not deliberately ignored, rather it was a lack of knowledge about the purpose and benefits of listening to the problem-solving process that limited productive interactions.

\subsubsection{Cycle 2 and 3: more productive listening}

In the EDR study, an understanding about the impact of the social aspects connected to listening led to changes in the communicative roles assigned to the students in the second and third cycles. The descriptions were shortened, with more concrete assignments related to the purposes for listening for problem solving. The analysis of the first cycle led to a discussion 
between the teacher and researcher about establishing socio-mathematical norms which required students to listen to others explaining their mathematical thinking and requesting clarifications about that thinking.

The emergence of nascent socio-mathematical norms can be seen in Transcript 2, where all four students participated in the problem-solving discussion. Although there were times when they still seemed uncertain about why they were asking questions - Azad's utterance in line 3 did not follow on from what was said before or after - they did not talk over the top of each other as they had in cycle 1 . This indicates that as listeners, they had begun to respect each other's contributions to the joint problem solving, and as speakers, they felt that their contributions were valued. They were then able to come to a better understanding of the problem and identify key information needed to solve it. Consequently, the students began to show productive listening, through a willingness to listen as well as to request listening from others.

In Transcript 4 from the third cycle, the importance of asking clarifying questions for supporting the problem-solving process was evident. In this example, Aisha, Carlos, and Mariam tried to find a formula for the mathematical sequence 5, 8, 11, 14, 17. Aisha suggested 3n +2 (cycle 3: Aisha, Carlos, Mariam, 30:26).

Transcript 4.

1 Aisha: Three " $n$ " plus two. One multiplied by three.

2 Mariam: One times three plus two, that is five. Here, it is, what is it?

3 Carlos: Eight

4 Mariam: Eight. And here it is eleven.

5 Carlos: Yes.

6 Aisha: What is a figure?

7 Mariam: That is the number you want to have.

8 Carlos: But what is three? I mean..., n3, what is that?

9 Mariam: Three. It increases by three.

10 Carlos: All that?

11 Mariam: All, all that. It increases by three.

12 Carlos: And add two? That is?

13 Mariam: Two. We had from the beginning; we had only two, because it increases by three.
Aisha: Tre n plus två. Ett gånger tre.

Mariam: Ett gånger tre plus två, det blir fem. Här, det blir, vad var det?

Carlos: Åtta.

Mariam: Åtta. Och här det blir elva.

Carlos: Ja.

Aisha: Vad är figur?

Mariam: Alltså vilket nummer du vill ha.

Carlos: Men vad är trean? Alltså ..., n3, vad blir det?

Mariam: Tre. Det ökar med tre.

Carlos: Alltså hela den?

Mariam: Hela, hela den. Det hela ökar med tre.

Carlos: Och plus två? Det är?

Mariam: Två. Vi hade från början, vi hade bara två, för det ökar med tre.

In Transcript 4, as in Transcript 2, the students' discussion led to the joint construction of a problem-solving process. The students asked questions, not because the communicative roles required them to do so, as had been the case with Azad's questions in cycles 1 and 2, but because they expected to gain useful information. In line 2, Mariam restated Aisha's idea about the formula, taking the role of a spokesperson (Krummheuer, 2015). However, in line 6, Aisha asked a question, showing she had not understood the task. In doing this, she requested listening, perhaps because she recognised that it was important for her to not just let the others solve the problem. By continuing to ask questions, Carlos showed that he had not understood Mariam's suggested solution but was willing to listen to see if the solution strategy worked or needed improving. The socio-mathematical norms about expecting to listen to each other's mathematical thinking and asking clarifying questions seemed to be established as the group members operated in accordance with them. 
In the interviews in these later cycles, the students indicated that they were aware of the need to be productive listeners by requesting listening and showing a willingness to listen. Amal described the purpose of listening in mathematical problem-solving work, "because we realised that it was better if you listened to everyone's opinions, since then you could more easily find the answer" (Interview cycle 3: Amal, Azad, Mohammed, 3:25). This ability to solve problems together was connected to the social aspects of respecting the speaker as someone with valuable knowledge and feeling that a contribution would be respected by others. In Transcript 5 (Final interview, cycle 3: Amal, Azad, Mohammed, 21:15), when asked about making sure everyone took part in the discussions, Mohammed answered:

\section{Transcript 5 .}

1 Mohammed: Through asking. Through really listening and not just ask... through really asking and trying to answer in a good way, or in any way, but really show that she or he has your attention. So that he or she feels like yes, I am part of the group, the others listen to me.
Mohammed: Genom att fråga. Genom att verkligen lyssna, inte bara fråga... genom att verkligen fråga och försöka svara på ett bra sätt, eller på vilket sätt som helst, men verkligen visa att hon eller han har din uppmärksamhet. Så att han eller hon ska ändå känna att jo, jag är med i gruppen, de lyssnar på mig.

In his reflection, Mohammed stated it was important that other members of the group felt respected, which he could show through his actions as a listener. By doing this, he was reducing the social risk that speakers might feel (Lack, 2010) in putting forward their ideas.

\section{Conclusion}

The productive listening framework overcomes some of the problems identified from using more general models of communication in mathematics education (Alrø \& Skovsmose, 2004; Fuentes, 2009) for analysing the role of listening in problem solving group work. This framework does this by showing how different aspects affect how and why students listen.

Given the difficulties identified with earlier definitions of listening in mathematics classrooms, we defined productive listening as involving two parts: requesting that others listen and a willingness to listen to others. This provided an opportunity to identify when and if students in small groups, solving mathematical problems, were engaged in productive listening. We were able to do this by looking, for example, at how the students utilised each other's ideas or asked questions when working together. From our perspective, passive listening could not be considered productive because it was not contributing to the joint construction of the problem solving process.

Productive listening is the result of a number of aspects interacting together. These included the purposes for listening which were loosely connected to Polya's (2014) stages of problem solving in that they focused on understanding the problem, identifying key information and determining if the solution strategy needed adjustment. However, the willingness to listen for these purposes was dependent on the students' respecting each other's contributions to the solution process and feeling that their own contributions would be respected. The social aspects were intertwined with the purposes of listening 
into two socio-mathematical norms that developed over the EDR study. These norms were to do with expectations about expecting to listen to others' mathematical thinking and asking clarifying questions when necessary.

The productive listening framework provides insights into the complexity associated with listening. It synthesises previous research on listening by focussing on student listening in mathematical problem-solving groups. This provides insights into, for instance, how Krummheuer's (2015) spokesperson and ghostee gained the structures or the content in their discussions and which contributed to their learning. Although we do not use the productive listening framework to discuss whether or not learning occurred, it can provide insights into what might be necessary if group work is to produce learning from engaging in joint problem solving.

The development of the productive listening framework arose from the difficulties in the EDR study to do with understanding how to improve student-to-student interaction in the problem solving groups. The two frameworks about mathematical communication, the IC-model (Alrø \& Skovsmose, 2004) and QCR-pairs (Fuentes, 2009), were not sufficient for understanding the complexity that contributed to students' listening, for instance on why and how students listen. From the literature review and the analysis in the EDR study, the different factors of productive listening were identified. However, there is a need for further research studies to test the productive listening framework in other contexts.

By using the productive listening framework to reanalyse the data from the EDR study, changes in students' listening were identified. In the later cycles, students began to understand the different purposes of listening to each other and how these were related to social aspects of respecting each other's contributions. Identifying the importance of respecting each other's contributions may support teachers to provide "a fair distribution of opportunities to learn or opportunities to participate" (Esmonde, 2009 , p. 1010). Awareness of the need for this respect and the connection to the purposes for listening led to the establishment of socio-mathematical norms about listening to others' mathematical thinking and asking clarifying questions. Hence, the framework can be used for further research projects but also for intervention studies which have the purpose of improving students' possibilities for learning through problem solving group work.

Previous research had mostly focused on the role of the teacher in listening in mathematics classrooms (see, for example, Hintz \& Tyson, 2015). Although others such as Boaler (2011) have acknowledged the need for teachers to develop students' listening to support their engagement in mathematics learning, there has been little work on how students learn to listen. The productive listening framework provides a language for describing how to improve student-to-student interactions by focussing on the interconnections between the different aspects that it outlines. In future EDR studies, we will use this framework to understand how it could support understanding group work with different mathematical topics or with groups of students, such as those who share other multiple languages or who do not share a first language.

This would enable us to check the productive listening framework's robustness in other circumstances, both in regard to designing teaching tasks but also in understanding how those tasks can be improved to match the specific needs of students. 
Acknowledgements Tamsin Meaney's contribution to this research is part of the Learning about Teaching Argumentation for Critical Mathematics Education (LATACME) in multilingual classrooms project that is funded by the Research Council of Norway.

Funding Open access funding provided by Malmö University.

Open Access This article is licensed under a Creative Commons Attribution 4.0 International License, which permits use, sharing, adaptation, distribution and reproduction in any medium or format, as long as you give appropriate credit to the original author(s) and the source, provide a link to the Creative Commons licence, and indicate if changes were made. The images or other third party material in this article are included in the article's Creative Commons licence, unless indicated otherwise in a credit line to the material. If material is not included in the article's Creative Commons licence and your intended use is not permitted by statutory regulation or exceeds the permitted use, you will need to obtain permission directly from the copyright holder. To view a copy of this licence, visit http://creativecommons.org/licenses/by/4.0/.

\section{References}

Alrø, H., \& Skovsmose, O. (2004). Dialogue and learning in mathematics education. Intention, reflection, critique. Kluwer Academic Publishers.

Artz, A. F., \& Armour-Thomas, E. (1992). Development of a cognitive-metacognitive framework for protocol analysis of mathematical problem solving in small groups. Cognition and Instruction, 9(2), 137-175.

Barnes, M. (2005). "Outsiders" in a collaborative learning classroom. In M. Goos, C. Kanes, \& R. Brown (Eds.), Proceedings of the fourth international mathematics education and society conference (pp. 58-69). Centre for Learning Research, Griffith University.

Bishop, J. P. (2014). "She's always been the smart one. I've always been the dumb one": Identities in the mathematics classroom. Journal for Research in Mathematics Education, 43(1), 34-74.

Boaler, J. (2011). Changing students' lives through the de-tracking of urban mathematics classrooms. Journal of Urban Mathematics Education, 4(1), 7-11.

Carpenter, T., \& Fennema, E. (1992). Cognitively guided instruction: Building on the knowledge of students and teachers. In W. Secada (Ed.), Researching educational reform: The case of school mathematics in the United States. A special issue of International Journal of Educational Research (vol. 17, pp. 457-470).

Cobb, P., \& Gravemeijer, K. (2008). Experimenting to support and understand learning processes. In A. E. Kelly, R. A. Lesh, \& J. Y. Baek (Eds.), Handbook of design research methods in education: Innovations in science, technology, engineering, and mathematics learning and teaching (pp. 68-95). Routledge.

Cobb, P., Stephan, M., McClain, K., \& Gravemeijer, K. (2001). Participating in classroom mathematical practices. The Journal of the Learning Sciences, 10(1\&2), 113-163.

Cohen, E. G., Lotan, R. A., Scarloss, B. A., \& Arellano, A. R. (1999). Complex instruction: Equity in cooperative learning classrooms. Theory Into Practice, 38(2), 80-86.

Davis, B. (1996). Teaching mathematics: Toward a sound alternative. Taylor \& Francis.

Davis, B. (1997). Listening for differences: An evolving conception of mathematics teaching. Journal for Research in Mathematics Education, 28(3), 355-376.

Esmonde, I. (2009). Ideas and identities: Supporting equity in cooperative mathematics learning. Review of Educational Research, 79(2), 1008-1043.

Fuentes, S.Q. (2009). The evolution of one teacher's interactions with students working in small groups to improve their communication, self-regulating, and problem-solving skills. [Doctoral dissertation, Montclair State University].

Hintz, A., \& Tyson, K. (2015). Complex listening: Supporting students to listen as mathematical sense-makers. Mathematical Thinking and Learning, 17(4), 296-326.

Hintz, A., \& Tyson, K. (2015). Complex listening: Supporting students to listen as mathematical sense-makers. Mathematical Thinking and Learning, 17(4), 296-326.

Hunter, J. (2009). Developing a productive discourse community in the mathematics classroom. In R. Hunter, B. Bicknell, \& T. Burgess (Eds.), Crossing divides: Proceedings of the 32nd annual conference of the mathematics education research group of Australasia (pp. 249-256). MERGA.

Kosko, K. (2014). What students say about their mathematical thinking when they listen. School Science and Mathematics, 114(5), 214-223. 
Krummheuer, G. (2015). Methods for reconstructing processes of argumentation and participation in primary mathematics classroom interaction. In A. Bikner-Ahsbahs, C. Knipping, \& N. Presmeg (Eds.), Approaches to qualitative research in mathematics education. Examples of methodology and methods (pp. 51-74). Springer.

Lack, B.S. (2010). Student participation in mathematics discourse in a standards-based middle grades classroom. [Doctoral dissertation, Georgia State University].

McKenney, S., \& Reeves, T. (2012). Conducting educational design research. Routledge.

Mueller, M., Yankelewitz, D., \& Maher, C. (2014). Teachers promoting student mathematical reasoning. Investigations in Mathematics Learning, 7(2), 1-20.

Otten, S., Herbel-Eisenmann, B. A., Cirillo, M., Steele, M., \& Bosman, H. M. (2011). Students actively listening: A foundation for productive discourse in mathematics classrooms. Paper presented at the Annual Meeting of the American Educational Research Association. LA: New Orleans.

Palmér, H. (2016). What is the difference? Young children learning mathematics through problem solving. In I. T. Meaney, O. Helenius, M. L. Johansson, T. Lange, \& A. Wernberg (Eds.), Mathematics education in the early Years (pp. 255-266). Springer.

Reeder, S. L., \& Abshire, G. E. (2012). Talking about the Greek Cross. Mathematics Teaching in the Middle School, 17(9), 558-563.

Reeder, S. L., \& Abshire, G. E. (2012). Talking about the Greek Cross. Mathematics Teaching in the Middle School, 17(9), 558-563.

Sfard, A. (2008). Thinking as communicating. In Human development, the growth of discourses, and mathematizing. Cambridge University Press.

Sjöblom, M. (2014). Coordinating the IC-model with a framework on communication in analysing student-tostudent interactions in mathematics. In H. Silfverberg, T. Kärki, \& M. S. Hannula (Eds.), Studies in subject didactics 10, Nordic research in mathematics education: proceedings of NORMA14, Turku, June 3-6, 2014 (pp. 349-358) https://helda.helsinki.fi/bitstream/handle/10138/159388/AD-14_Norma.pdf

Sjöblom, M. (2015). Promoting student-to-student interactions in mathematics: A study in a multilingual upper secondary classroom. Malmö studies in educational sciences. Licentiate dissertation series, 2015, 40 http:// muep.mau.se/bitstream/handle/2043/18939/2043_18939_Sj\%C3\%B6blom_MUEP.pdf?sequence= 2\&isAllowed=y

Walshaw, M., \& Anthony, G. (2008). The teacher's role in classroom discourse: A review of recent research into mathematics classrooms. Review of Educational Research, 78(3), 516-551.

Webel, C. (2010). Collective cognitive responsibility in the high school mathematics classroom. [Doctoral dissertation, University of Delaware].

Publisher's note Springer Nature remains neutral with regard to jurisdictional claims in published maps and institutional affiliations. 